\title{
A Reflection on the Concept of Youth as Identity in Literary Journals in Italy a Century Ago
}

\author{
APOLLONIA STRIANO \\ astriano@unior.it \\ University of Naples "L'Orientale"
}

\begin{abstract}
This contribution aims to develop some observations on the concept of identity with specific reference to a particular historical moment, the period just before the First World War, in a particular context, Italy, in which young intellectuals compared their ideas and debated with each other in periodicals. Through the collation of two manifestos, published in two journals in distant geographical areas, and of the experiences of the two publishing houses, we have tried to verify the dogma itself of the writing and the communicative action, perceived as an indispensable stimulus to engagement, to the aesthetic composition of another world and to the tacit evocation of the miracle of a new beauty.
\end{abstract}

\section{Post-modernity and the dogma of identity}

In the broad and undefined watercourse of post-modernity, according to the sociologist Zygmunt Bauman (1993), the process of the breaking down of the boundaries of identity has reached an extreme point, implying a resetting of the essential references of the ego in cultural, religious and ethnic terms.

At this point in history, the controversial dogma of identity - on which philosophical, anthropological, psychological and sociological reflections have focused over time - no longer takes the form of an absolute status but of a process that connects events and people. Identity is thus a place of memory (Parfit, 1984) and, at the same time, a historical product in which elements and transversal factors occurring in the community co-exist. Its most intrinsic dimension, however, concerns individuality, that is, the individual and her/his formation, which, in its refraction within the social assembly, can find confirmation or opposition.

Solid, modifiable only after gradual changes, bound to coherence and set in the values that govern social behaviour, identity needs to be narrated, recounted in its own paradigm. Literature thus participates in its construction, contextually divulges it and gives it tradition: those who write know how to do this for themselves but know that they are also tools to give shape and immortality to the ideas of an entire generation and a context. 


\section{Literature and the shaping of processes of identification: the case of literary magazines in Italy at the beginning of the twentieth century}

For the reasons discussed in the previous section, in the literary system, genres and languages have always been reworked, remodelled, bent out of shape to deliver new and clear visions of the world and to provide certainties able to activate processes of identification. In Italy, in the first decade of the twentieth century, this function was performed above all by literary magazines, in whose publishing houses - which developed spontaneously in the major cities - young intellectuals came together eager to provide their ideological contribution. Their manifestos, with which they opened their periodicals, were declamatory, often naive, but they managed to give voice to their pressing demands and their plans for the future. They exalted literature as a no man's land, unrelated to and yet capable of affecting reality. This tension crossed the whole country: from Milan to Florence, from Naples to Catania, new or as yet unknown writers put themselves to the test, as a group, movement or school, trying to strengthen their individuality in a programmatic design of their common identity. Leonardo (1903), La Voce (1908) and Lacerba (1913), founded in Florence were among the first and most successful experiments. In particular, La Voce by Giovanni Papini and Giuseppe Prezzolini was taken as a model - to be emulated or refuted - in other contexts, with extraordinary results. This is what happened in Naples, where Gherardo Marone, a young man, passionate about Italian and Spanish literature, created La Diana in 1915, a magazine in which Giuseppe Ungaretti also published. Ten years later, Marone himself - for exalted and unavoidable moral reasons - openly sided against Mussolini's regime, signing the courageous Manifesto degli intellettuali antifascisti (Manifesto of the Anti-Fascist Intellectuals) drawn up by the philosopher Benedetto Croce, as an extreme attempt to stem the blind brutality and violence of fascism.

Marone's subsequent journey - precisely as a result of this youthful courageous and radical stance - took him into voluntary exile in Argentina. The mature, adult period of his life was spent there, his time divided between the teaching of Italian literature at the University of Buenos Aires and the promotion of Italian studies.

From the very start, in his early attitudes and positions, the future developments and potentialities that would later assume a more substantial and solid form already seem to be discernible. In this sense, the manifesto with which the adventure of La Diana gets underway - starting with the programmatic title Il manifesto degli Ardimentosi (The Manifesto of the Fearless) - was proposed as a well-defined corollary, in which were listed the constitutive principles of the existential dimension itself, precisely that of youth, presented as a dogma of identity. This was stated in Il manifesto degli Ardimentosi (La Diana 1990 [1915]: 1-2):

\footnotetext{
"Art, which is the most spontaneous and pure aspiration of the soul, expressed or experienced in a superior form, sometimes becomes the vulgar lust of infinite turmoil, the most certain means of life, the shining sphere that contains a handful of mud, the beautiful chrysalis that hatches the unclean worm. But for the host of the Fearless she remains forever as the first form of life, as the root of the world, the only wonderful reality. Divine poetry is in the most beautiful song, in the contemplation of the blazing dawn and also in the exaltation that evokes the roar of a heart of steel which, on pure white wings, soars into the blue of the skies. But the sense of perfect beauty is the patrimony of the initiates and for this reason these new Fearless fight their full battle; they achieve the spiritual exodus of the artistic republic in order not to hear the cries of the crowd and not to suffer the impulse of the currents. [...] Thus, this small band, having finally overcome the charms of
} 
common life, retire to the summit of their own spirit to pursue an ideal of perfection, regardless of popular opinion. However, they will also want to follow different pathways from this new height, to draw out the most beautiful shapes and blend them into a single perfection. The multiplicity of life in its full humanity, in its frantic race and also in its metallic form, they aim to grasp and follow and express as motive and action, as thought and beauty; thought, though, springing up free from the different schools and always understood as a progression of art to which it is intimately connected. Among all the currents defined without scholastic preconceptions we pursue with tenacious determination only the search for the truth in its most noble expression, and, among its infinite tendencies, we aim to discover in pure contemplation, even in the face of the assaults of all, a higher ideal of beauty". Thus, in more modest words, speaks Il Manifesto degli Ardimentosi, which is both a proclamation and an appeal! [...] "Whoever fights a passionate battle to contend against the poetry and thought at the discordant schools is worthy of being listened to with the most religious attention".

\section{Identity and the rhetoric of youth}

This statement, this collective stance, was a common declaration of intent from a group of young people who, just before the Great War, were attempting to participate in the intellectual debate, which at that time was taking place by means of manifestos and periodicals. Thus, the artistic proclamations of the Ardimentosi ended up being the ambitious declarations of a young generation who were trying to define their cultural identity and intending to distinguish and identify with their fingerprints the new status of literature. Strengthened by a rhetorical construction that dissolved weaknesses and inconsistencies in the name of inexperience, the Dianisti were preparing to fight an incredibly difficult battle: it was a case of gaining credibility, of making their works known, of being evaluated, of being considered part of an avant-garde movement from the south of Italy which others would have to take into account. In short, La Diana intended to sketch out an alternative Italian literary geography in the second decade of the 1900s, balancing the strong influence that the other Italian magazines exercised. In this perspective, it seems necessary to consider again what had been affirmed in the manifesto reported at the opening of the second issue of La Voce, commissioned by Papini and Prezzolini when they were in their early twenties (Prezzolini, 1908: 5):

We do not promise to be geniuses, to dissect the mystery of the world and to determine the precise and daily menu of actions that is needed to become great men. But we promise to be honest and sincere. We do not promise to never make any mistakes, because, in a certain sense, this is impossible; but we promise to correct ourselves as soon as we realize the error, and this, believe me, is almost more rare than never being wrong and is, in any case, more precious. We believe that Italy needs character, sincerity, openness and seriousness rather than intelligence and spirit. [...] We strongly feel the ethics of intellectual life, and it makes us vomit to see the misery, the hardship and the revolting trafficking that is made of things of the spirit. [...] These are the infinite forms of arbitrariness that we intend to denounce and fight. Everyone knows them, many talk about them; but nobody points them out publicly.

These are superficial and reckless judgements without any possibility of discussion, the quackery of deficient artists and thinkers without any backbone [...] the profit and the profession of the manufacturers of literature, the empty form that in itself solves every problem. [...] But let us be clear. We do not want to advance into useless outbursts, into 
childish tantrums. We always intend to stay firm, and to try to make fruitful the abandoned fields [...] La Voce must not be a cenacle of slanderers or a permanent inquisition. We will try all means to seriously collaborate in the practical and theoretical progress of Italian culture. Indeed, we will wait for the past generation, which has its hands on the rudder, to give us the opportunity to use for the common good that bit of common sense and not unworthy intelligence that many are now conceding to us. We will not make opposition until the ways of understanding and agreement to promote the seriousness and sincerity of Italian life are exhausted. We are keen to work. We already aim to keep up with certain social movements that are convoluted with ideologies, such as Modernism and Syndicalism; to provide information, without any obsession for novelty, about what is better performed abroad; to propose reforms and improvements to public libraries, to address the moral crisis of the Italian universities; to highlight the works worth reading and to comment on the cowardice of contemporary life.

There are the constituent elements as announced in La Voce from which evidently the La Diana movement did not intend to distance itself. The youth were proposed as an exalted group, free from "useless outbursts", foreign to "childish tantrums" (Prezzolini, 1908: 5) and capable of presenting themselves in a constructive relationship with the previous generation. This represented a strong statement, which implicitly revealed a determined thought. Such was the reflection of the philosopher Benedetto Croce. As one of the financial sponsors and scientific supporters of the Florentine journal, he gave an unequivocal address, expressing a clear and dialectical identity with the common, shared conception of youth.

Indeed, in relation to this group, the philosopher nurtured "a respect and also the impatience of a physiologically sound nature, which does not like to confuse the boundaries of generations" (E. Croce, 1979: 126).

Foreign to all complacency and to every empty indulgence towards young people, Croce did not accept the rampant rhetoric that justified their most fanciful expectations, placing above everything the alleged sacredness of their needs. Instead, he considered it essential that they think about working, about making themselves useful to society (Cecchi, 1965).

La Voce, therefore, praised a constructive, and accordingly an ethical, aesthetics, valid for the construction of a common modern Italian cultural heritage.

A few years later, Marone's magazine, born right in the city where Croce's teaching was inescapable, revealed an equally proactive approach. From Naples, where the conditionings of the realist and realistic tradition persisted, the effects of a strong dialectal production appreciated and firmly established among intellectuals and readers, Marone, together with his group of brave, young, as yet unknown supporters (Annunzio Cervi, Fiorina Centi, Mario Cestaro, Rocco Galdieri, Elpidio Jenco and Mario Venditti), tried, through the foundation of his avant-garde publication, to obtain space and visibility.

They had been moved by an awareness that the means of cultural dissemination were changing. In this new context, in fact, a periodical could be the quickest tool to allow the circulation of literary programs and to give space to new and unknown authors, at the margins of the main literary circles

Its very structure as a magazine-workshop contributed to legitimizing its proceeding by trial and error, through the audacious and profitable combination of different elements and the acceptance of foreign influences. The establishment of connections with international 
collaborators, Apollinaire, Cendrars, Tzara, albeit sporadic, guaranteed to La Diana the form of an experimental collective organism with an extended identity, open to external ideas.

In this way, fearlessly, these young writers claimed the right to participate in the definition of a new culture, notwithstanding the fact that war was beginning to press down upon them. Many of them were called to the front as soldiers. The experience of pain and mourning for the loss of family and friends was felt by all. And yet, they persevered in asserting the value of literature, as if in a hypnagogic state, while violence raged outside and everything seemed wrapped in a curtain of uncertainty, contrasting the moral and concrete ruins of the surrounding reality with the aesthetic composition of another world and the tacit evocation of the miracle of a new beauty.

Their unshakable confidence in the strength and sacredness of the communicative action the only measure of civilization to contrast with the dark irrationality of so many events allowed them to leave unpublished contributions in the literary landscape, which was beginning to include and find inspiration in ideas until that time peripheral to the general debate.

However, shortly afterwards, this admirable, productive tension began to subside. There occurred an implosion of La Diana, forced to close due to the accumulation of difficulties. Various typographical problems were in fact added to the continuous economic hardships, including limitations in distribution.

Literature, which had always been a space of compensation and order, was now agitated by opposing forces, which, even if they collected twentieth-century hues, crepuscular, futurist echoes of conservatism and embryonic solutions from hermetic poetry, were never able to draw a clear aesthetic line, nor to deliver to the near future a definitive idea of identity.

For La Diana, there was a collapsing in on itself, in search of singular and most authentic justifications, which seemed to mark - almost at the same time - the final moment of the history of La Voce. However, in the case of the Florentine magazine, the long and extreme pars destruens - which lasted from 1914 to 1916, the year in which its activities ceased completely took place in the manner of a verification, a moment of recognition of the achievement of further expressive possibilities. In this phase La Voce passed under the guidance of Giuseppe De Robertis, who tried to reaffirm the totalizing value of literary practice, free from problems and responsibilities in relation to reality. Exclusively centred on itself, with no historical and Immanentist implications, the magazine managed to be reborn temporarily, resolving itself in pure poetry and fragmentary poetry ('poetica del frammento'). The inclination towards totalizing poetry - which implied its osmosis with prose - led Vocianism along the same trajectory as European Expressionism (Contini, 1988).

The young editors thus redefined their artistic physiognomy, aligning themselves with the avant-garde movements that were advancing in Europe, in general under the aegis of Negativism and Iconoclasm. In the face of the pressing demands of a context dominated by war and all the unpredictable economic, anthropological, social and ideological implications that this activated, they reacted with nihilistic detachment, proclaiming the separateness of art. And if in the more provincial areas Italy responded "with a loud voice", proclaiming Futurism, the Vociani acted and worked "more quietly", enlisting themselves in an innovative role that "will be recognized more slowly" (Martignoni, 1993: 199). The 'poetica del frammento', sketched out under the direction of De Robertis, was premonitory, proceeding by symbols and analogies in a shattered, syncopated, very dense discourse. In this form - which would then 
be promptly taken up and fully developed by Hermeticism - the generation of the Vociani had indicated the essence of its new style, as well as the viaticum to survive in itself.

It was not the same, it has been said, for the La Diana group. In this case, the vague formula of their rhetoric on youth, delivered as a tautological aesthetic programme, proved too weak and confused to resist the war, the rapid evolution of the political structure, and the diffusion of other philosophical dogmas and another mythography of art.

Marone understood that he could not invest further in his literary magazine, in which there had been proclaimed intentions too vague, unbalanced and naive to take root, find a following, or nurture a real school. Therefore, he closed the story of La Diana by tracing an ogive curve, which in Croce and in his own system had found the point towards which to strive. Only in this direction could he have resumed his journey: with the support of an idealistic system, exercising criticism of itself, in the definition of a mature identity, in which form and content, past and present, aesthetics and ethics found reconciliation.

\section{Keywords}

Benedetto Croce; Gherardo Marone; Giuseppe Ungaretti; Giuseppe Prezzolini; Giuseppe De Robertis; La Diana; La Voce; youth; identity; First World War

\section{References}

Bauman, Z. (1993), Modernity and Ambivalence, Cambridge: Polity.

Carpi, U. (1979), Giornali Vociani, Rome: Bonacci.

Contini, G. (1988), Ultimi Esercizî ed Elzeviri (1968-1987), Turin: Einaudi.

Croce, E. (1979), L'Infanzia Dorata e Ricordi Familiari, Milan: Adelphi.

D’Antuono, N. (1990), La Diana [original reprint], Cava de' Tirreni: Avagliano.

Gaglione, M. (1918), Gherardo Marone: I Giovani, Caserta: Tipografia dell'Unione.

Habermas, J. (1986), Teoria dell'Agire Comunicativo, Bologna: il Mulino.

Invitto, G. (1980), La Mediazione Culturale: Riviste Italiane del Novecento, Lecce: Milella.

Langella, G. (1989), Da Firenze all'Europa: Studi sul Novecento Letterario, Milan: Vita e Pensiero.

Langella, G. (1996), Gherardo Marone, Naples: Macchiaroli.

Luti, G. (1983), Firenze Corpo 8: Scrittori, Riviste, Editori nella Firenze del '900, Florence: Vallecchi.

Marone, G. (1920), Difesa di Dulcinea, Naples: Libreria della Diana.

Martignoni, C. (1993), "Sulla Letteratura Vociana: La Riforma dei Generi e dello Stile", Strumenti Critici, 72: 189-203.

Parfit, D. (1984), Reasons and Persons, Oxford: Clarendon Press.

Prezzolini, G. (1908), “La Nostra Promessa”, La Voce, I (2): 5.

Prezzolini, G. (1909), Benedetto Croce: Con Bibliografia, Ritratto e Autografo, Naples: Ricciardi e Associati.

Prezzolini, G. (1915), “Il Manifesto degli Ardimentosi”, La Diana, I (1): 1-2.

Simonetti, C.M. (1981), Le Edizioni della Voce, Florence: La Nuova Italia. 